\title{
1:5,000 geological map of the upper Cretaceous intraplatform-basin succession in the "Gravina di Matera" canyon (Apulia Carbonate Platform, Basilicata, southern Italy)
}

\author{
Vincenzo Festa (*), Luisa Sabato $(*)(* *)$ \& Marcello Tropeano (*)
}

\section{ABSTRACT}

Along the slopes of the "Gravina di Matera" canyon, below and in front of the "Sassi di Matera", i.e., the old Matera town (Basilicata, southern Italy), an about $200 \mathrm{~m}$ thick succession of upper Cretaceous carbonates extensively crops out. These carbonates belong to the Apulia Carbonate Platform and, in the official geological map, are referred to the Calcare di Altamura Fm, a lithostratigraphic unit composed of shallow-marine peritidal limestones.

In order to study the whole outcropping succession, a geological survey was performed in the area and an unexpected intraplatform shallow-basin suite of limestones has been recognized within the Calcare di Altamura Fm. On the basis of lithologic characters, the whole succession has been divided into informal lithostratigraphic units a-g. The base of the succession (unit a) is represented by a crudely stratified bioclastic floatstone-rudstone locally interested by in situ brecciation, a phenomenon that often is the precursor of deep changes in a carbonate platform. Unit a sharply passes upward to thinly bedded and finely planar-laminated mudstone interested by slumps (unit b), conformably covered by dolostones (unit c). Dolostone gradually passes to cherty limestones (unit d) that in turn pass to wackestones (unit e) covered by a megabreccia (unit f). All these units (a-f) indicate that this area of the Apulia Platform performed a change from "classic" platform environments to slope- and to basin-ones, before the restarting of typical facies of shallow-marine carbonate platform environments (unit g).

This subdivision in units of the outcropping succession led us to informally define a member, the Matera member (ALT $)$, within the upper Cretaceous Calcare di Altamura Fm (ALT). Most likely, the Matera member (units a-f) represents a shallow-basin developed within the Apulia Platform during Late Cretaceous, most likely related to extensional tectonics. Other examples of slope-to-basin sedimentary suite were previously observed within the upper Cretaceous succession of the Apulia Platform and the occurrence of another shallow-basin in the interior of the same platform opens a new and still understimated regional tectonic and paleogeographic scenario.

Moreover, it should be highlighted that the study area belongs to a Regional Natural Park since the 1990 ("Parco Archeologico Storico Naturale delle Chiese Rupestri del Materano" also known as "Parco della Murgia Materana") and that Matera, besides being in the Unesco Word Heritage list since the 1993, has been voted European Capital of Culture 2019. Therefore, the obtained 1:5,000 geological map, apart from documenting some lithostratigraphic evidences of the intraplatform basin, represents an essential tool for both (i) future studies regarding the upper Cretaceous tectono-stratigraphic evolution of the Apulia Platform, and (ii) a geological base for many visitors interested in the cultural and geological heritage of Matera and its territory.

KEY wORDs: Apulia Carbonate Platform, intraplatform basin, late Cretaceous, Matera, geological heritage.

(*) Dipartimento di Scienze della Terra e Geoambientali, Università degli Studi di Bari "Aldo Moro", Bari, Italy. Studi di Bari "Aldo Moro", Via E. Orabona, 4, 70125 Bari. Corresponding author e-mail: vincenzo.festa@uniba.it.

$(* *)$ Dipartimento di Biologia, Università degli Studi di Bari "Aldo Moro", Bari, Italy.

\section{INTRODUCTION}

Along the spectacular "Gravina di Matera", a canyon eroded by the homonymous stream (i.e., "Torrente Gravina di Matera"), and on whose right slope lies the town of Matera (Basilicata, southern Italy) (Fig. 1), a some hundreds of meters thick succession of Cretaceous limestones, belonging to the Apulia Platform and unconformably covered by Plio-Pleistocene deposits, crops out. In order to investigate the Cretaceous succession we began to study the best exposed part of it, just below and in front of Matera town. Here, through serendipity, an unexpected intraplatform-basin succession, vertically characterized by several different lithostratigraphic units, has been found. Previous geological surveys of the area have never dealt with details of the Cretaceous succession, since either were realized at a regional scale or mainly regarded some geotechnical features of the upper Pliocene-lower Pleistocene calcarenites into which the old town of Matera (a rupestrian village) is dug (BoEnzI et alii, 1971; 1976; RADINA, 1973; Cotecchia \& Grassi, 1975; Maggiore et alii, 1975; Baldassarre, 1990; Mucciarelli et alii, 2002). In order to know the lateral extension, relationship and evolution of each Cretaceous lithostratigraphic unit exposed in the area, a 1:5,000 geological map has been realized (see the additional material, hereafter main map).

A wide debate deals with the possibility that Cretaceous sinsedimentary tectonics could have affected the Apulia Platform and adjacent areas; the occurrence of an intraplatform basin in a carbonate platform is an intriguing feature that often is interpreted as a signal of sindepositional tectonics. The only structural data referred to Cretaceous tectonics collected in Apulia carbonate successions of the Murge area (FESTA, 2003) suggest the development of synsedimentary tensional and/or transtensional structures. This interpretation is in accordance with the possibility to create conditions for local increase in accommodation, that could has been recorded either by a local thickening of the inner-platform succession or by the development of isolated depressions within the platform, with the occurrence of a shallow-basin suite of facies.

At the moment, only this last kind of sedimentary evidence has been observed to trace Cetaceous sindepositional tectonic deformation in the interior of the Apulia Platform, and the Matera example could represents an additional element for the study of upper Cretaceous tectonics using the sedimentary record. 


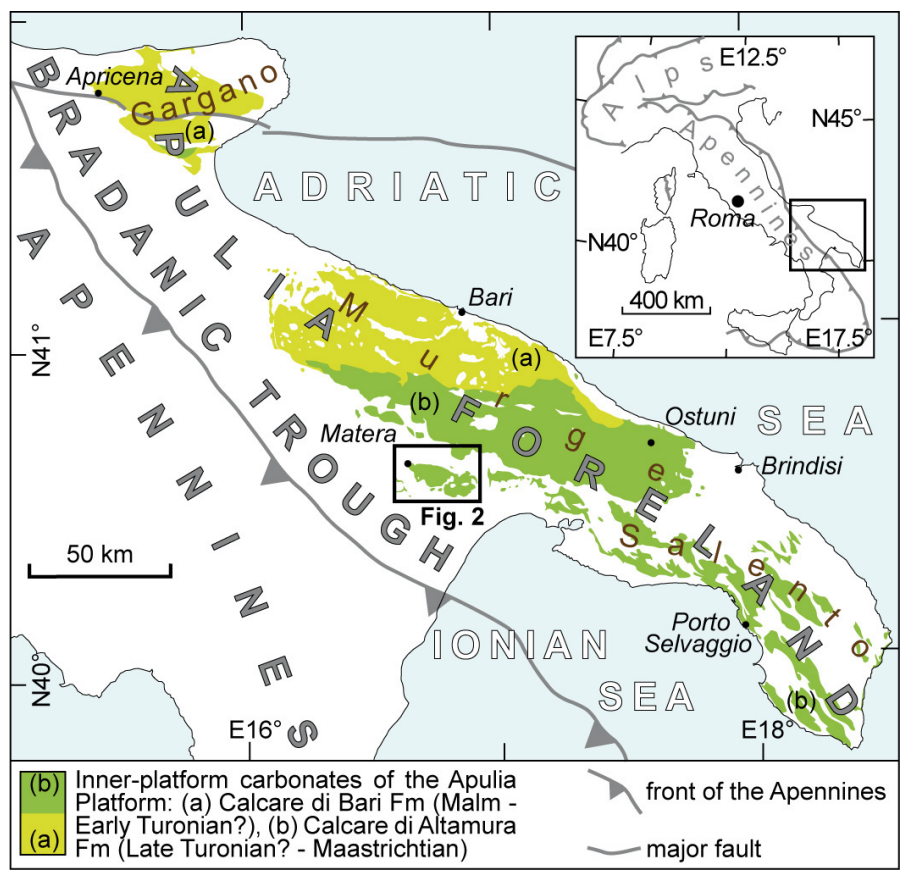

Fig. 1 - Outcrops in the Apulia Foreland (southern Italy), of the inner-platform carbonate rocks belonging to the Apulia Platform (modified after Ciaranfi et alii, 1988, Tropeano et alii, 1997, and SPALluto et alii, 2005).

\section{GEOLOGICAL SETTING}

The study area is located on the western side of Murge, at the boundary between the foreland (Apulia Foreland) and the foredeep (Bradanic Trough) domains of the southern Apennines orogenic system in Italy (Fig. 1). The Apulia Foreland comprises three different morpho-structural highs that, from NW to SE, correspond to the Gargano, Murge, and Salento areas (e.g. Ricchetтा et alii, 1988) (Fig. 1). Outcropping rocks on the Apulia Foreland mainly record the development of a Mesozoic carbonate platform (the Apulia Platform), whose Cretaceous succession is extensively exposed in the Murge area, where two vertically stacked formations, the Calcare di Bari Fm (below) and the Calcare di Altamura Fm (above), basically made up of inner platform facies, crop out (PIERI, 1980; CIARANFI et alii, 1988; RicchetTi et alii, 1988) (Fig. 1).

As regards the Bradanic Trough, the same Cretaceous limestones of Murge represent the bedrock of the PlioPleistocene succession of the foredeep on its foreland side (Ciaranfi et alii, 1979; Sella et alii, 1988) (Fig. 2). Here, the Bradanic Trough succession starts with upper Pliocene-lower Pleistocene shallow-marine coarse-grained carbonates (the Calcarenite di Gravina Fm) (Fig. 2), whose transgression and backstepping on the Murge high, exposed since the end of the Cretaceous, record the intense subsidence induced by the eastward Apennines migration (Tropeano \& Sabato, 2000). Since, during exposure, the Murge area was represented by a horst and graben system, a wide archipelago developed during this relative sea-level rise (i.e., the foreland subsidence). The progressive flooding of the subsiding foreland led the arrival of lower Pleistocene hemipelagic clays (the Argille subappennine Fm) from the Apennines. These clays onlapped onto the flanks of the islands, previously mantled by the coarse-grained carbonates, and were successively covered by lower and middle Pleistocene coastal to fluvial sands and gravels (regressive coastal and alluvial deposits, sensu PIERI et alii, 1996), that almost completely hid the bedrock features. These sands and gravels are the result of a regional uplift, started from late early-Pleistocene times; later, erosion and drainage network deepening, favoured by this continuous uplift, determined the partial dismantling of the foredeep succession and the exhumation of some morphostructural features of the old archipelago (TRopeano et alii, 2002). One of the partly exhumed paleoisland is the Matera Horst, that corresponds to the "Murgia materana" area, about $50 \mathrm{~km}^{2}$ wide and up to about $520 \mathrm{~m}$ high (Fig. 2), where the study area lies. According to Boenzi et alii (1971) and Servizio Geologico d'Italia (1971), the Cretaceous bedrock is made up of upper Cretaceous limestones of the Calcare di Altamura Fm, composed of inner platform limestones rich in rudists, with interbedded bodies of dolostones or breccia of uncertain continental origin. As occurred in the whole Murge area, these faulted Cretaceous rocks were exposed up to the upper Pleistocene, when the foreland subsidence induced a relative sea-level rise on the

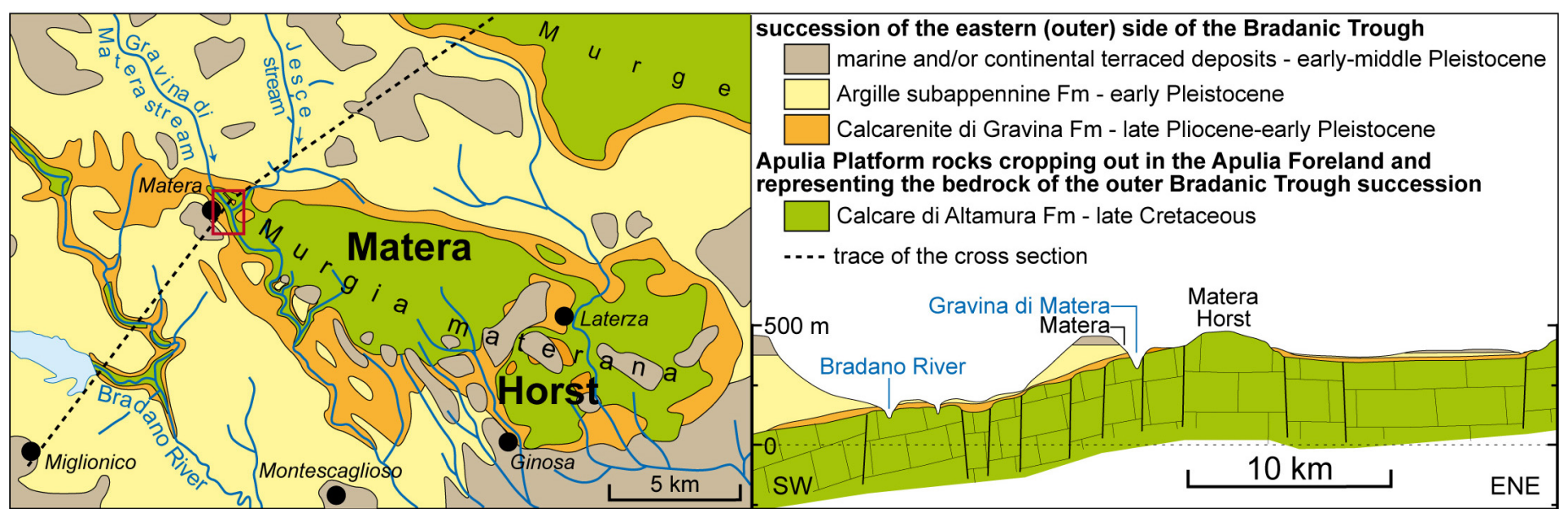

Fig. 2 - Geological scketch map around Matera, on the outer side of the Bradanic Trough (see Fig. 1 for the location), and cross section (vertical exaggeration; modified after BENEDuce et alii, 2004). The red rectangle indicates the area of the main map. 
Matera Horst also. The top of this paleoisland was never reached by the sea. But on each side of the horst remnants of the described foredeep succession (Plio-Pleistocene calcarenites, clays and coarse-grained siliciclasts) may be observed. Natural sections of both the foredeep (Bradanic Trough) succession and its Cretaceous bedrock are today well exposed in the Matera area. The exposition is due to both the regional Pleistocene uplift affecting Murge (DogLioni et alii, 1994) and locally the occurrence of the "Gravina di Matera" canyon. At least since about $0.75 \mathrm{Ma}$, after cutting the foredeep cover, the canyon is deepening in the carbonate bedrock of the southwestern flank of the paleoisland (Fig. 2) (BENEducE et alii, 2004).

\section{METHODS AND MAP PRODUCTION}

The topographic base used for the geological mapping is represented by portions of the sheets n. 472123 and n. 472124, scale 1:5,000 of the Carta Tecnica Regionale Regione Basilicata, available online (http://rsdi.regione. basilicata.it/web/guest/home) as TIFF files of maps georeferenced in ETRS89. By the use of Adobe ${ }^{\circledR}$ Illustrator $^{\circledR}$ software, the main map vector, the geological cross sections and the legend were designed. Graphically, the main map refers to the standard symbols, colors and filling defined for the making of the in progress official 1:50,000 Geological Map of Italy (AвBAтE et alii, 1992; Cosci et alii, 1996; TACCHIA, 2007; BATTAGLini et alii, 2009).

For the characterization of the carbonate lithotypes, some more detailed observations were carried out on sawn slabs from rock samples.
The lithostratigraphic criterion was adopted for the geological mapping of the upper Cretaceous succession, that was divided into various informal lithostratigraphic units on the basis of the solely lithologic peculiarities (see Hedberg, 1976; Abbate et alii, 1992; Salvador, 1994, for a compherensive discussion on the stratigraphic classification and terminology).

\section{THE GEOLOGICAL MAP}

The proposed 1:5,000 geological map derives from a geological survey that concentrated on the Cretaceous carbonate succession cropping out along the well exposed sides of the "Gravina di Matera" canyon, below and in front of the old town of Matera, called "Sassi di Matera" (see the main map for the following described litostratigraphic and structural features). The other outcropping units of the studied area, i.e., those referred either to the Bradanic Trough cycle or to much more recent covers, have been reported in the main map to show their areal distibution only.

Since the early stages of the geological survey, it was immediately clear that the outcropping Cretaceous succession was characterized by different mappable lithosomes and affected by several faults. Since lithosomes are vertically stacked and each lithosome exhibits peculiar facies features, the Cretaceous succession has been subdivided into seven informal lithostratigraphic units, named from a to g, upward (e.g. Fig. 3a,b). This subdivision has been useful to describe the different facies characterizing the development of the Cretaceous succession and has represented an essential tool to highlight and evaluate the faults displacements.

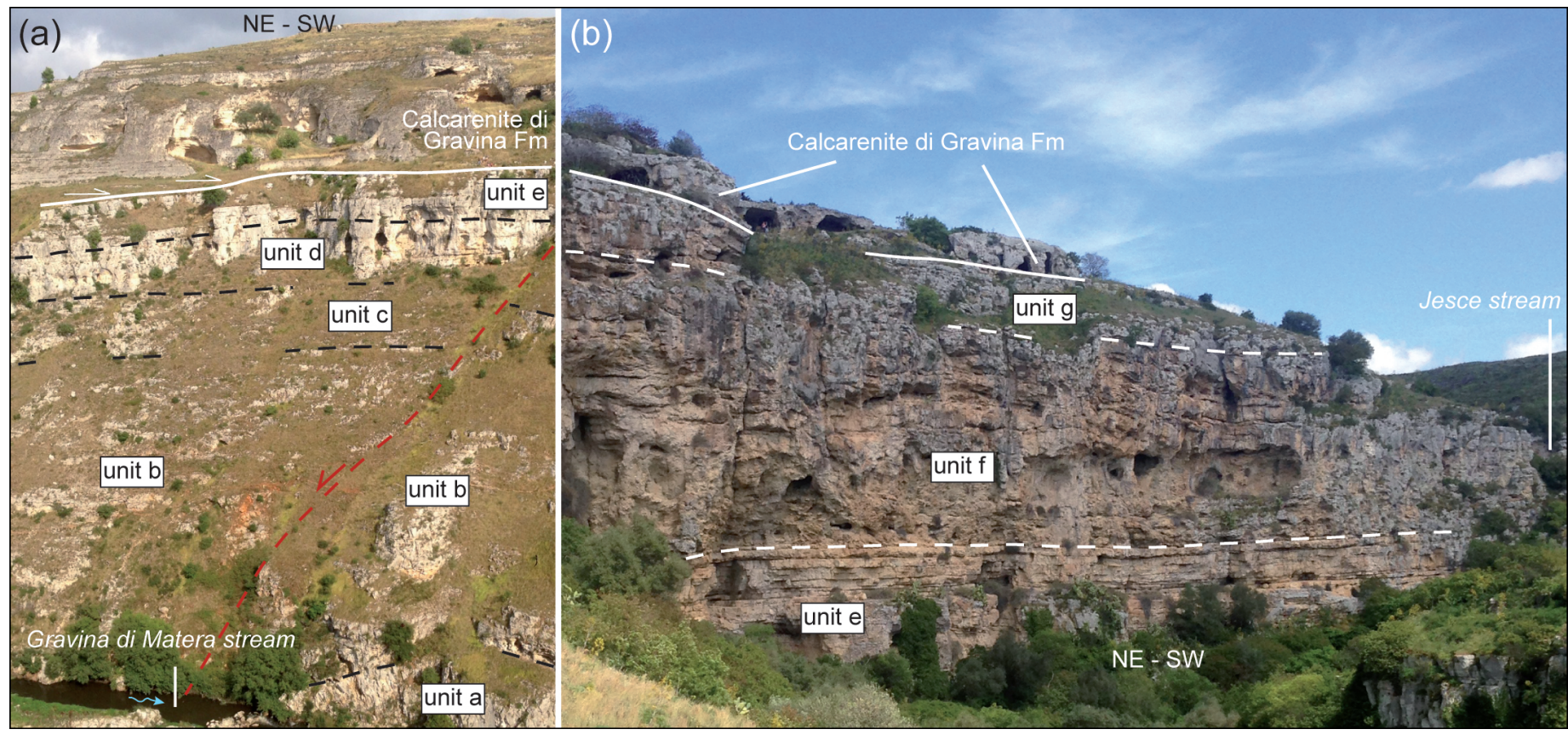

Fig. 3 - (a) View of the left slope of the "Gravina di Matera" canyon (the height of the slope is ca. 90-100 m) in front of S. Lucia convent (see main map for the location of both "Gravina di Matera" canyon, eroded by the homonymous stream "Torrente Gravina di Matera", and S. Lucia convent, that is "Convento S. Lucia"). The black dashed lines indicate lithostratigraphic contacts between the Cretaceous informal units a-e; the continuous white line represents the unconformity at the base of the Calcarenite di Gravina Fm. A normal fault (red dashed line), displacing the Cretaceous bedrock not more than $10 \mathrm{~m}$, can be appreciated. (b) View of the left slope of the "Gravina di Matera" canyon (the height of the slope is ca. $50 \mathrm{~m}$ ), near the junction with the Jesce stream ("Torrente Jesce" in the main map). The white dashed lines indicate lithostratigraphic contacts between the Cretaceous informal units e-g; the continuous white line represents the unconformity at the base of the Calcarenite di Gravina Fm. 


\section{LITHOSTRATIGRAPHY}

According to the observed relationships and regional considerations, the mapped units have been subdivided into three main groups related to different paleogeographic/geodynamic steps of the evolution of the area. Their age has been assigned following the available chronostratigraphic data and, from the oldest to the youngest, the three groups belong to: i) the Apulia Carbonate Platform units, developed during the Mesozoic in a passive margin context; ii) the Bradanic Trough units, developed during the Pliocene and early Pleistocene in the Apennines foreland basin; iii) the Quaternary continental deposits, that are the sediments recording the last (uplift) stage of the Apulia Foreland evolution.

The oldest outcropping units represent the Cretaceous succession of the Apulia Platform, formally belonging to the Calcare di Altamura Fm. Locally this succession has been referred to the Senonian p.p. (BoEnzi et alii, 1971) and is up to $200 \mathrm{~m}$ thick. Its features are described in detail in the following sub-section.

The Calcarenite di Gravina Fm, unconformably lying on the Cretaceous succession (Fig. 3a), represents the transgressive deposit on the foreland rocks (i.e., the Cretaceous limestones of the Apulia Platform) and records the beginning of the Bradanic Trough infill succession. Locally it has been referred to the late Pliocene $p . p$. and early Pleistocene p.p. (Tropeano et alii, 1994), and is up to several tens of meters thick, like in the "Sassi di Matera". In the mapped area it is represented by coarse-grained mixed lithoclastic-bioclastic carbonates (calclithite and grainstone/packstone), frequently forming clinobedded bodies (Tropeano, 1994; Pomar \& Tropeano, 2001; Mateu-Vicens et alii, 2008). Locally, an extraclastic carbonate conglomerate, up to some meters thick, occurs at the base.

The Argille subappennine Fm, conformably lying on the previous formation, locally has been referred to the early Pleistocene p.p. (TRopeAno et alii, 1994) and is up to a few tens of meters thick; in the area this formation records the maximum deepening of the Bradanic Trough and is carachterized by silty clay and, in its uppermost part, by sandy silt.

The regressive coastal and alluvial deposits, either conformably lying on the Argille subappennine Fm or unconformably lying on the Calcare di Altamura Fm, represent the closure of the Bradanic Trough infill succession, and in the area have recorded the first stages of the foreland uplift. These deposits, up to some tens of meters thick and made up of siliciclastic sand and gravel, have been regionally referred to the early Pleistocene $p . p$. and to the middle Pleistocene p.p. (PIERI et alii, 1996; Tropeano et alii, 2002; BENEDuce et alii, 2004).

Finally, the Quaternary continental deposits record the uplift of the area accompained by the deep incision of the drainage network. They are basically made up of carbonate gravel, no more than about $10 \mathrm{~m}$ in thickness, and are represented by: i) late Pleistocene terraced alluvial deposits, ii) late Pleistocene-Holocene talus deposit, iii) late Pleistocene-Holocene alluvial deposit.

\section{The Cretaceous succession}

The seven vertically stacked informal lithostratigraphic units a-g, distinguished within the outcropping Cretaceous succession on the basis of the observed lithologic and sedimentologic peculiarities, will be described from the bottom upward. Due both to the pre-Pliocene morphology and structural setting of the Matera Horst, the units c-g can be unconformably covered by Plio-Quaternary deposits (see the main map).

\section{Unit a}

The unit a is made up of a bioclastic floatstone-rudstone characterized by $\mathrm{cm}$-large bivalvs. This unit locally shows a matrix- to clast-supported breccia texture, with irregular and mainly subangular clasts, up to $5-6 \mathrm{~cm}$ in size (Fig. 4a). Breccia texture is highlighted by a widespread network of $\mathrm{cm}$-spaced and disorganized open fractures filled by fine sediment (mudstone). The layering is not always evident; locally, massive layers up to $1 \mathrm{~m}$ thick can be observed (Fig. 4b). The thickness of the unit a, whose base is not exhibited, is about $25 \mathrm{~m}$. The unit a conformably passes upward to the unit b through a sharp contact (Fig. 4b).

\section{Unit b}

The unit $\mathrm{b}$ is represented by a thinly bedded and finely planar-laminated mudstone, with some set of laminae referable to flat to pseudocolumnar stromatolites (Fig. 5a,b). In the lower part of the unit, complex folds can be locally observed. These folds are interpreted as slump structures (e.g. Fig. 5c,d) being represented by deformed horizons, up to $2 \mathrm{~m}$ thick, sandwiched between undeformed facies of the same unit. An alternation of meter-thick horizons of laminated mudstone and dolostones indicates the passage between the unit $b$, that shows a maximum thickness of about $30 \mathrm{~m}$, and the overlying unit c (Fig. 5e).

\section{Unit c}

The unit $\mathrm{c}$ is basically composed of dark greyish dolostone (e.g. Fig. 5f), often carious, organized in bad defined massive layers up to $1 \mathrm{~m}$ thick in alternance with well-stratified centimeters to decimeters thick dolomitic limestones. The unit c, often showing karst dissolution features, exhibits a thickness of about $25 \mathrm{~m}$. The unit c conformably passes upward to the unit $d$ through a sharp stratigraphic contact.

\section{Unit d}

The unit d consists of a well-stratified cherty limestone succession. It is made up of brownish laminated marly mudstones and dolomitic limestones including dark greyish, dark brownish or whitish chert organized in nodules or gently undulated layers; both size of nodules and thickness of layers reach ca. $15 \mathrm{~cm}$ (Fig. 6a,b). Although the marly mudstone and the dolomitic limestone are generally more abundant of the chert, a 1:1 ratio between these carbonate and siliceous lithotypes can be locally observed (Fig. 6b). The unit shows a thickness of about $12 \mathrm{~m}$. The upward abrupt missing of chert marks the transition to the overlying unit e.

\section{Unit e}

The unit e is dominated by well-stratified ligth greyish/ whitish wackestone. The strata show a thickness on average of 20-30 cm and a lobate shape; the stratal surfaces are often characterized by stylolites (Fig. 7a). The unit, showing a thickness of about $30 \mathrm{~m}$, conformably passes upward to the unit $\mathrm{f}$ through a sharp stratigraphic contact (Fig. 7b). 

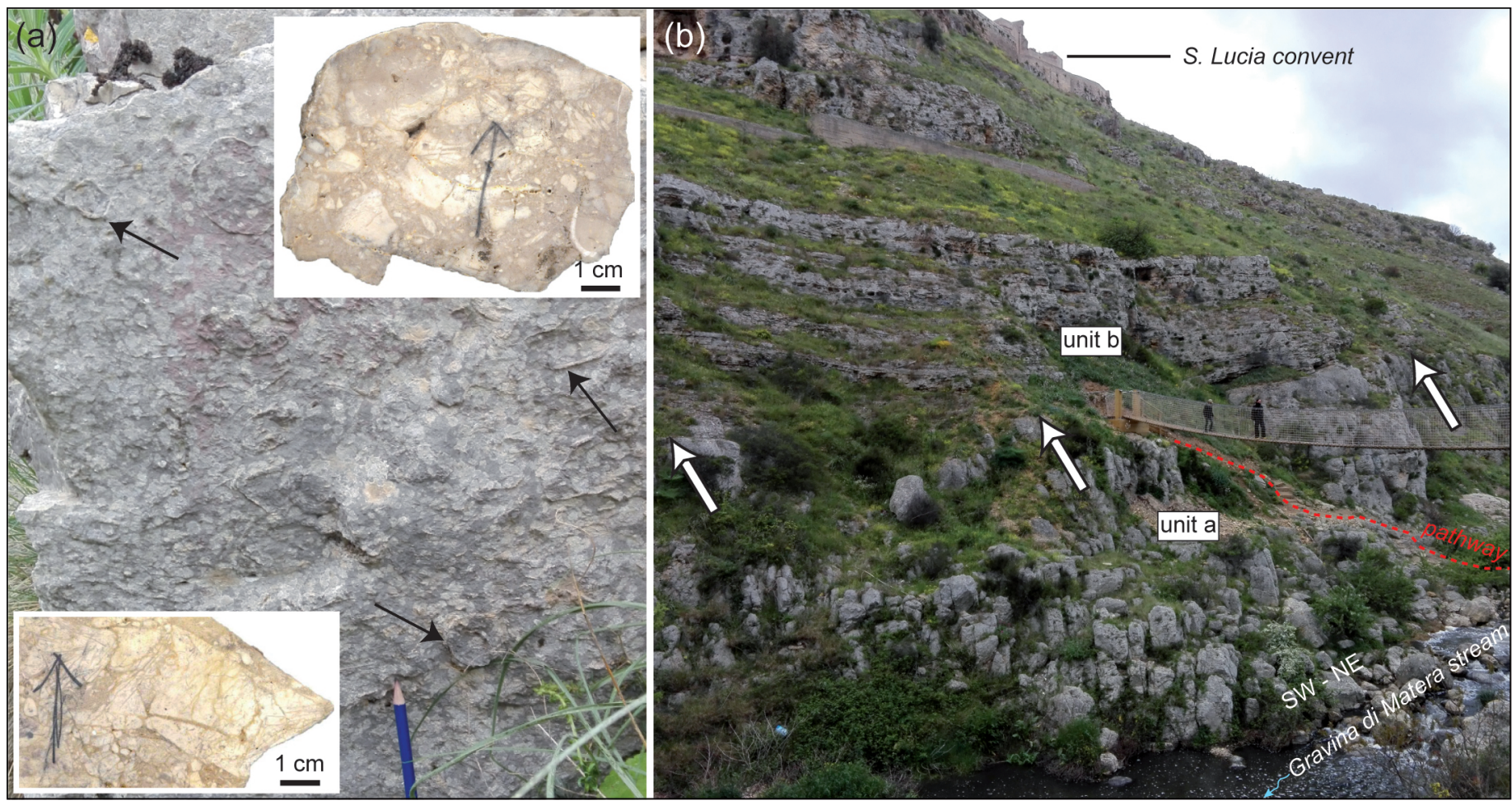

Fig. 4 - (a) Brecciated bioclastic-floatstone-rudstone of unit a; the arrows indicate some of the many bioclasts; scanning of slabs of rock samples are represented in the upper right and lower left (the arrows on the rock slabs indicate the top of the samples); irregular and subangular clasts can be appreciated in both slabs; matrix-supported texture is shown in the upper right slab, while clast-supported texture in the lower left one. (b) View of the outcrop of the unit a crossed by the pathway connecting S. Lucia convent (i.e., "Convento S. Lucia" in the main map) to the "Gravina di Matera" stream (i.e., "Torrente Gravina di Matera" in the main map), on the right slope of the "Gravina di Matera" canyon; the sharp contact with the conformably overlying unit $b$ is pointed by the arrows.

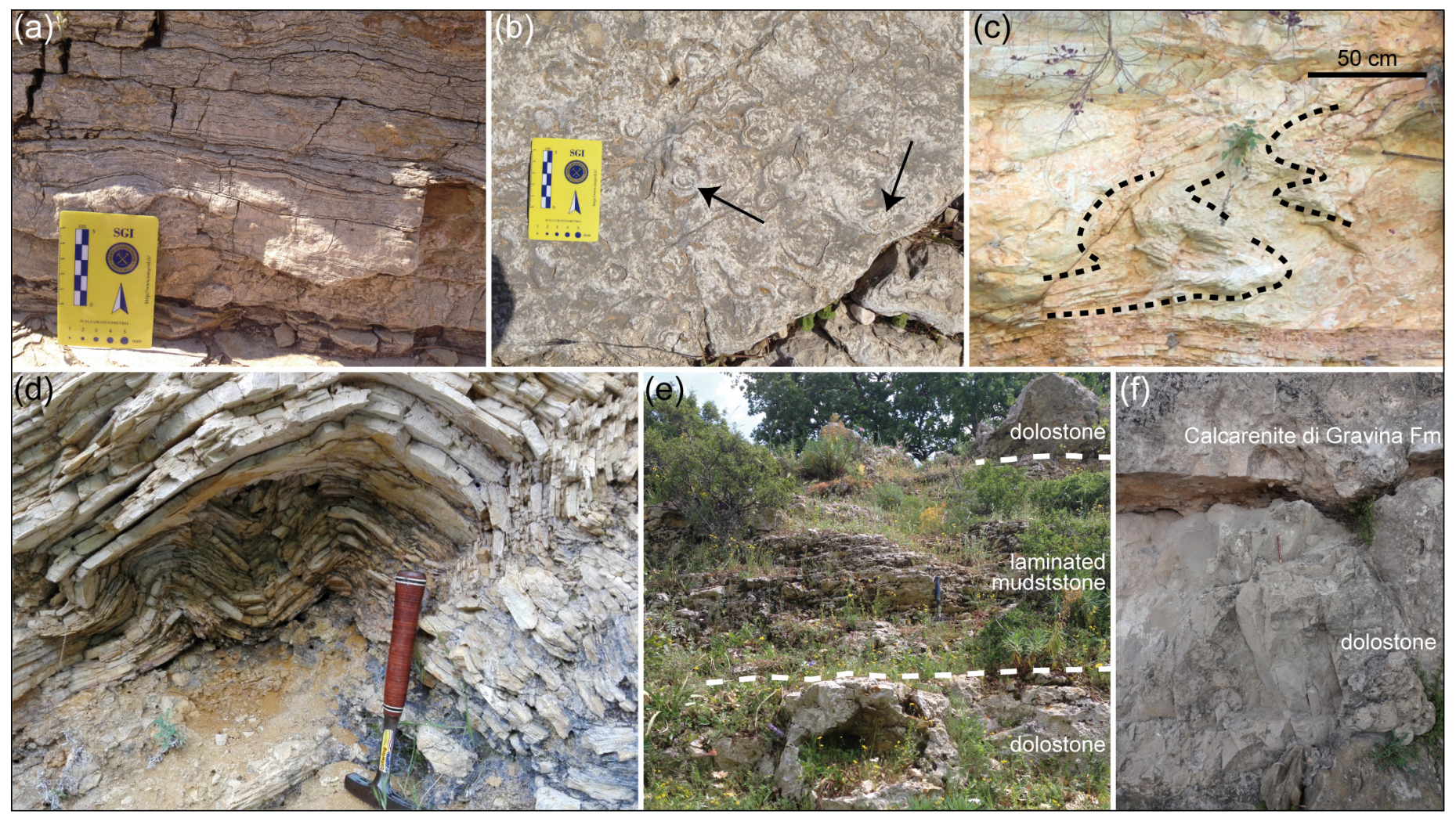

Fig. 5 - (a) Finely planar-laminated mudstone of unit b, characterized by flat to pseudocolumnar stromatolites laminae. (b) Stratal surface showing sub-circular, concentric geometries (some of which pointed by arrows) given by pseudocolumnar stromatolites laminae within the unit b. (c, d) Examples of slump-type deformations involving thinly bedded mudstone in the lower part of the unit b. (e) Alternation of meter-thick horizons of dolostone and laminated mudstone, in the lower part of the unit c. (f) Detail of the dolostone belonging to the unit c. 


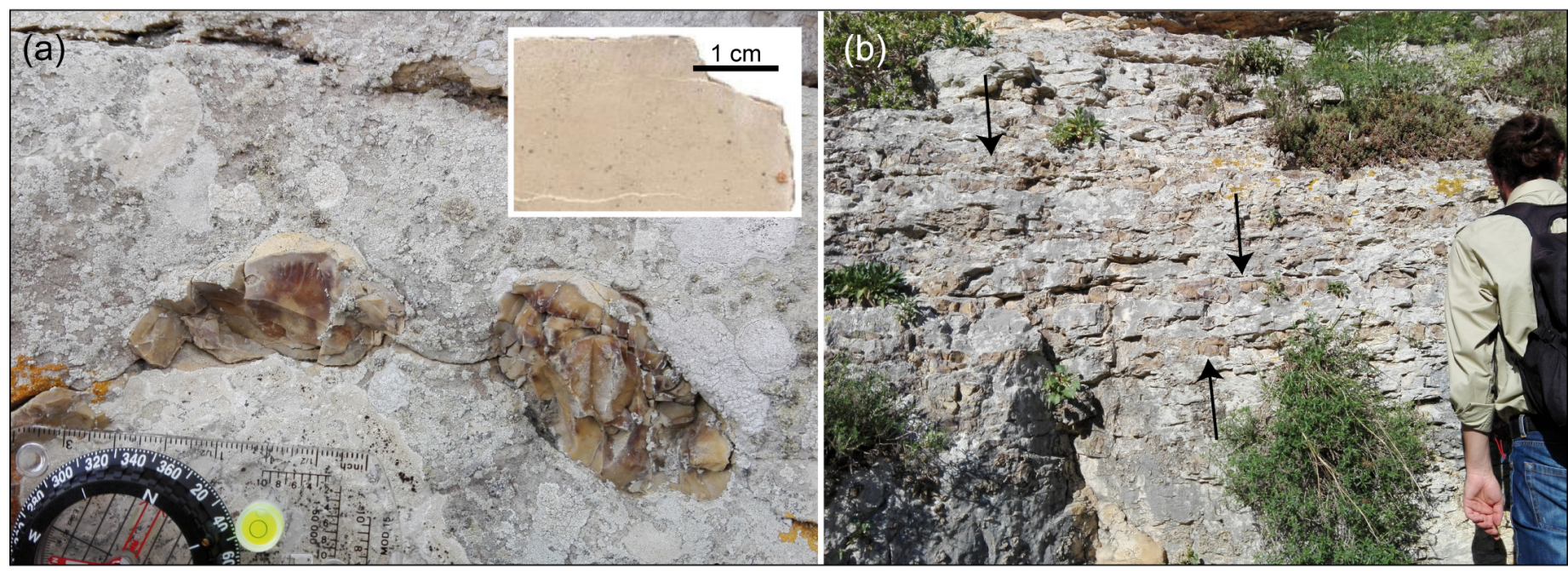

Fig. 6 - (a) Nodules of chert included in marly mudstone of unit d; the brownish color of the marly mudstone is shown in the scanning of slab of rock sample in the upper right. (b) Gently undulated cherty layers, some of which pointed by arrows, in unit d; a 1:1 ratio among chert and marly mudstone can be appreciated.
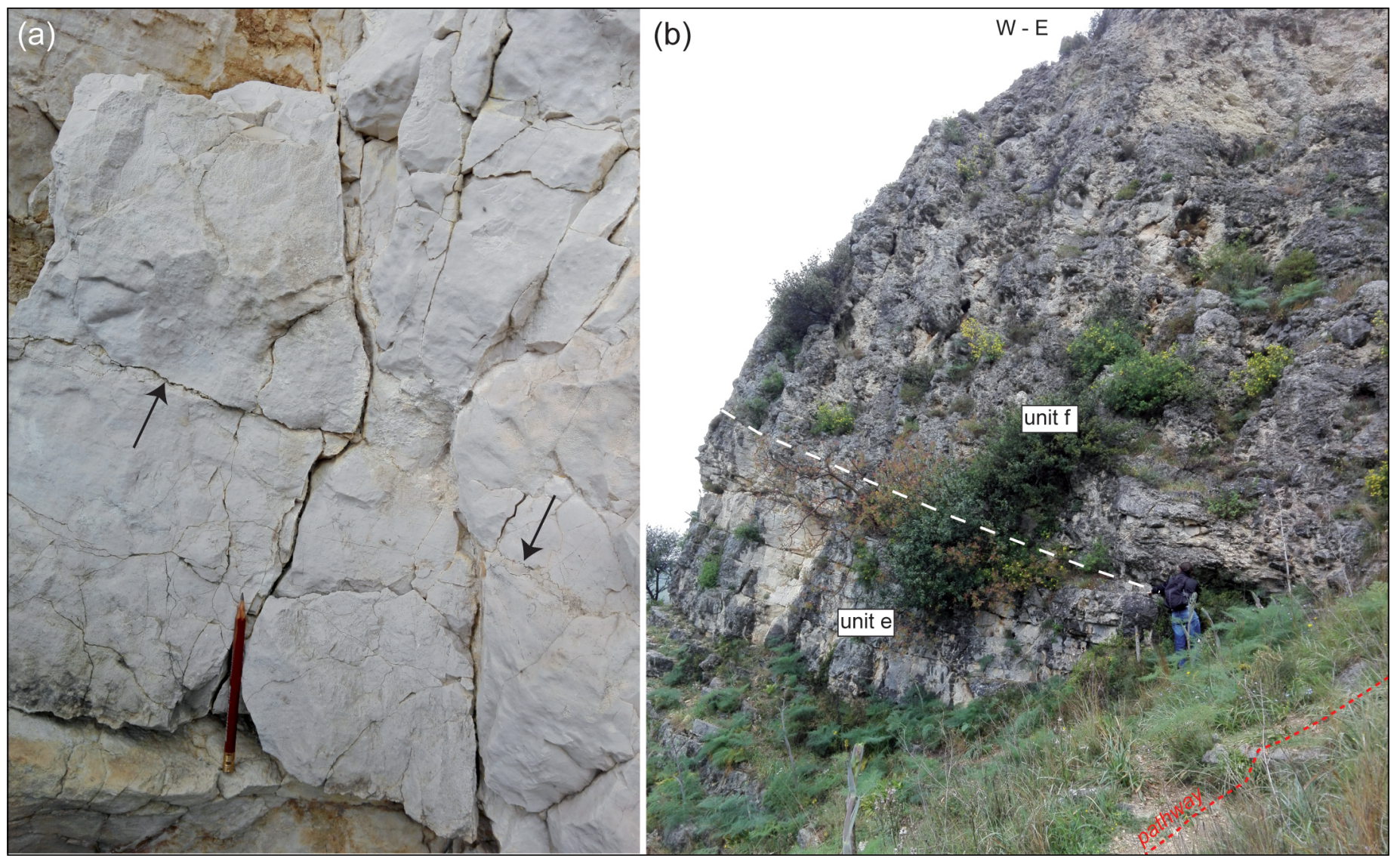

Fig. 7 - (a) Detail of the greyish/whitish wackestone belonging to unit e; the arrows point to some stylolitc surfaces. (b) View of an outcrop of unit e, covered by unit f, near the pathway connecting Madonna delle Vergini rupestrian church to the "Gravina di Matera" stream (i.e., "Torrente Gravina di Matera"; see main map for the location); the sharp stratigraphic contact between these two units is indicated by the dashed line.

Unit $\mathrm{f}$

The unit $\mathrm{f}$ is represented by a carbonate breccia (megabreccia) with re-sedimented limestone clasts having variable shape and size; diameter of clasts reaches $50 \mathrm{~cm}$ and some extrasized clasts are also present. The texture is generally clast supported, and occasionally matrix supported (Fig. 8a). Sometimes this disorganized breccia shows weak signs of stratification (Fig. 8b), and, at the base of the unit, dismembered and folded strata having texture features similar to those charac- 

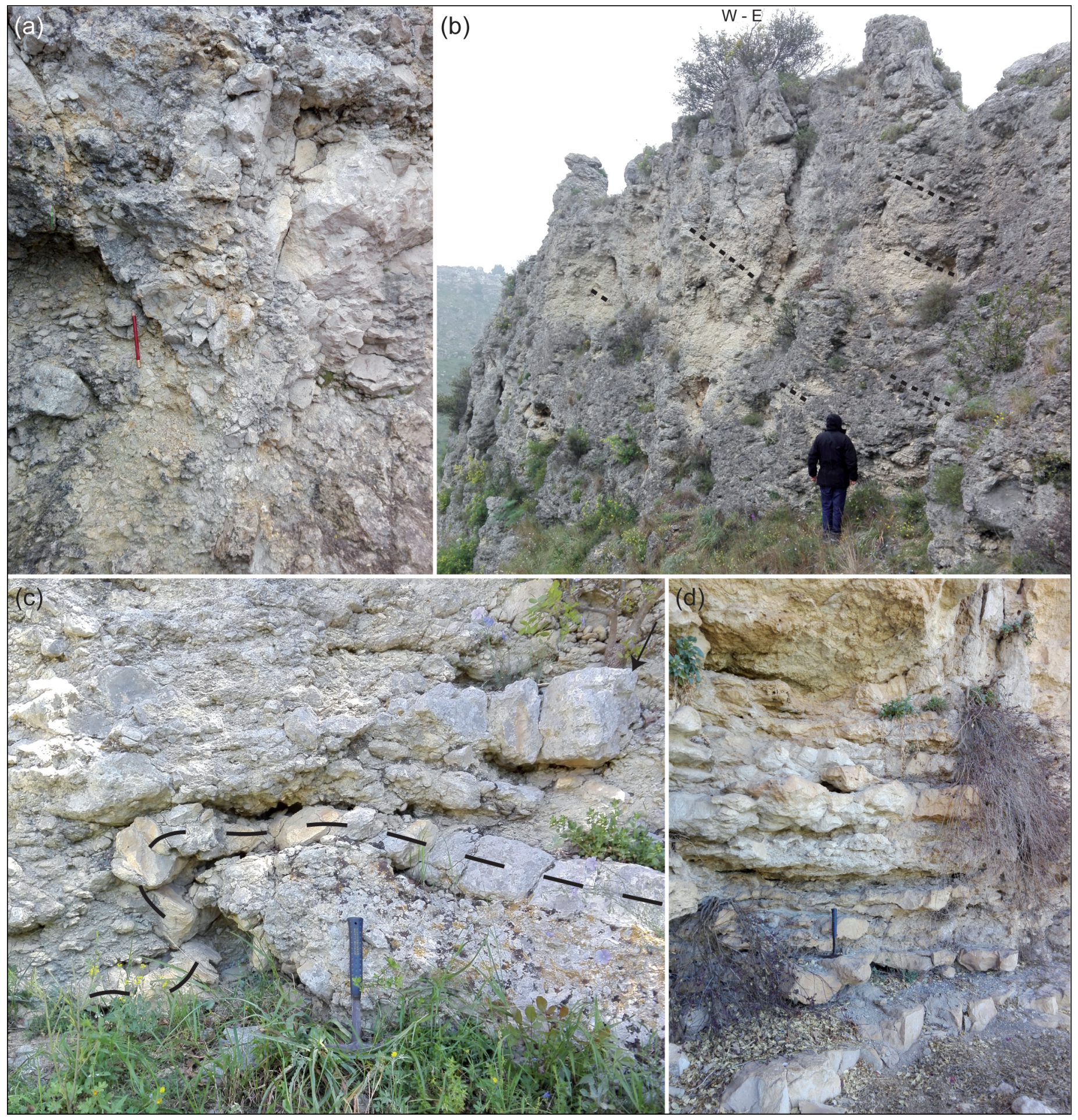

Fig. 8 - (a) Detail of the megabreccia of unit f; variable shape and size of limestone clasts and the clast supported texture can be appreciated. (b) Very weak stratification (dashed lines) within the megabreccia of unit f. (c) Folded layer (a dashed line have been traced in the middle of the layer) at the base of the unit f; a dismembered portion of an original layer within the unit $\mathrm{f}$ is pointed by the arrow. (d) Alternation of decimeter-thick breccia layers with gently undulated layers of mudstone (more protruding) in the upper part of unit $\mathrm{f}$.

terizing the unit e, can be found embedded in the breccia (Fig. 8c). Toward the top of the unit, decimeter-thick carbonate breccia layers alternate to gently undulated mudstone layers, that characterize the overlying unit g (Fig. 8d). The unit $\mathrm{f}$ exhibits a thickness of about 20 $\mathrm{m}$ and the upward missing of breccia layers marks the transition to the unit $\mathrm{g}$.
Unit g

The unit g, which represents the top of the Cretaceous succession in the mapped area, is dominated by tabular well-stratified ligth brown mudstone and very fine-grained packstone/grainstone in its lower part (Fig. 9a), and by rudists floatstone in its upper part (Fig. 9b). The strata thickness is variable from 20 to $40 \mathrm{~cm}$, and the stratal sur- 

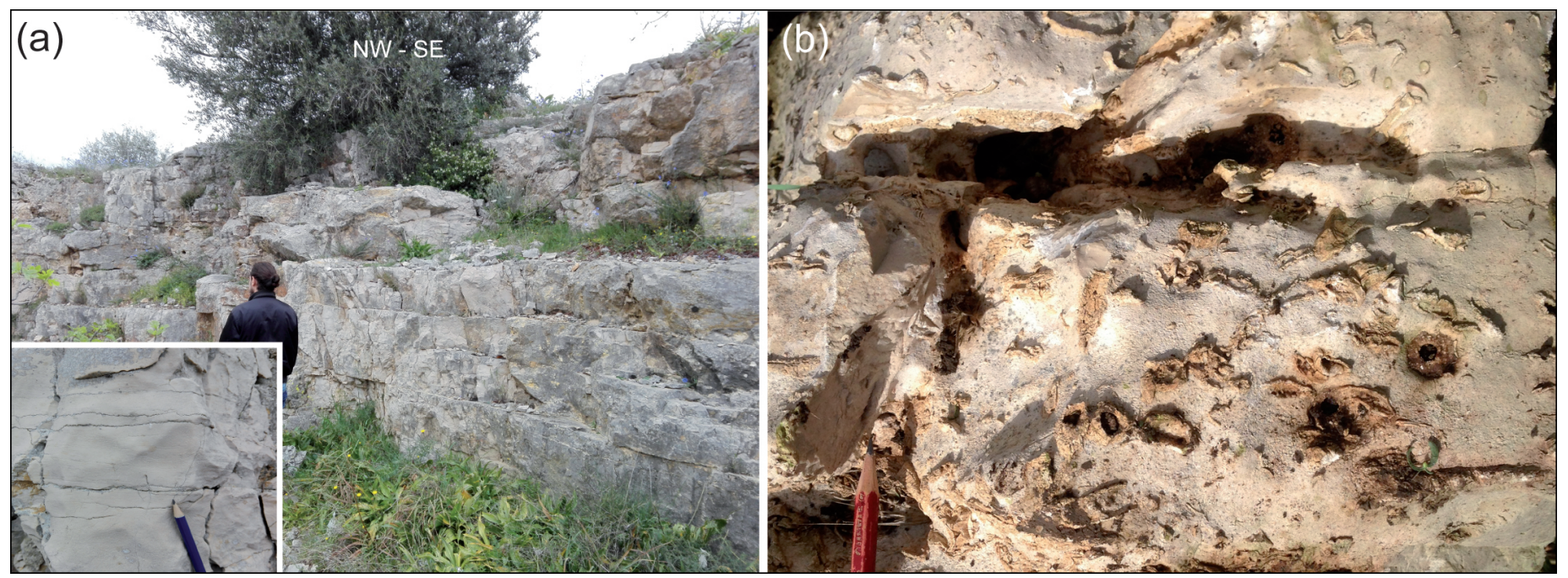

Fig. 9 - (a) Well-stratified mudstone and very fine-grained packstone/grainstone in the lower part of the unit g; the ligth brown color of the mudstone, and the stylolites characterizing some stratal surfaces can be appreciated in the lower left picture magnification. (b) Rudists floatstone in the upper part the unit g.

faces are often characterized by stylolites (Fig. 9a). The unit shows a thickness of about $60 \mathrm{~m}$, and it is widespread exposed along the upper part of the slopes of the "Gravina di Matera" canyon and on the top of this investigated part of the Matera Horst.

\section{MAIN STRUCTURAL FEATURES}

The Cretaceous succession is moderately tilted mainly to the northeast, southwest and northwest, owing to normal faults, to which, moreover, are locally associated gentle to open synclines and anticlines. The succession is widespread jointed along stratal surfaces and fractured, with an increasing of high-angle fracturing typically approaching the faults. Two main normal faults, with throw exceeding ca. $20 \mathrm{~m}$, have been observed. They are represented by two roughly opposite (diverging) northeast- and southwest-dipping faults (Fig. 10a,b), located towards the northeast and the southwest corners of the main map, respectively. Synthetic and antithetic faults can be found associated to these two main faults (e.g. Fig. 10b and geological section $\mathrm{C}-\mathrm{C}^{\prime}$ in the main map).

The main northeast dipping normal fault strikes from Murgecchia locality (to the northwest) to Jesce stream (i.e., "Torrente Jesce", to the southeast), and plunges of ca.

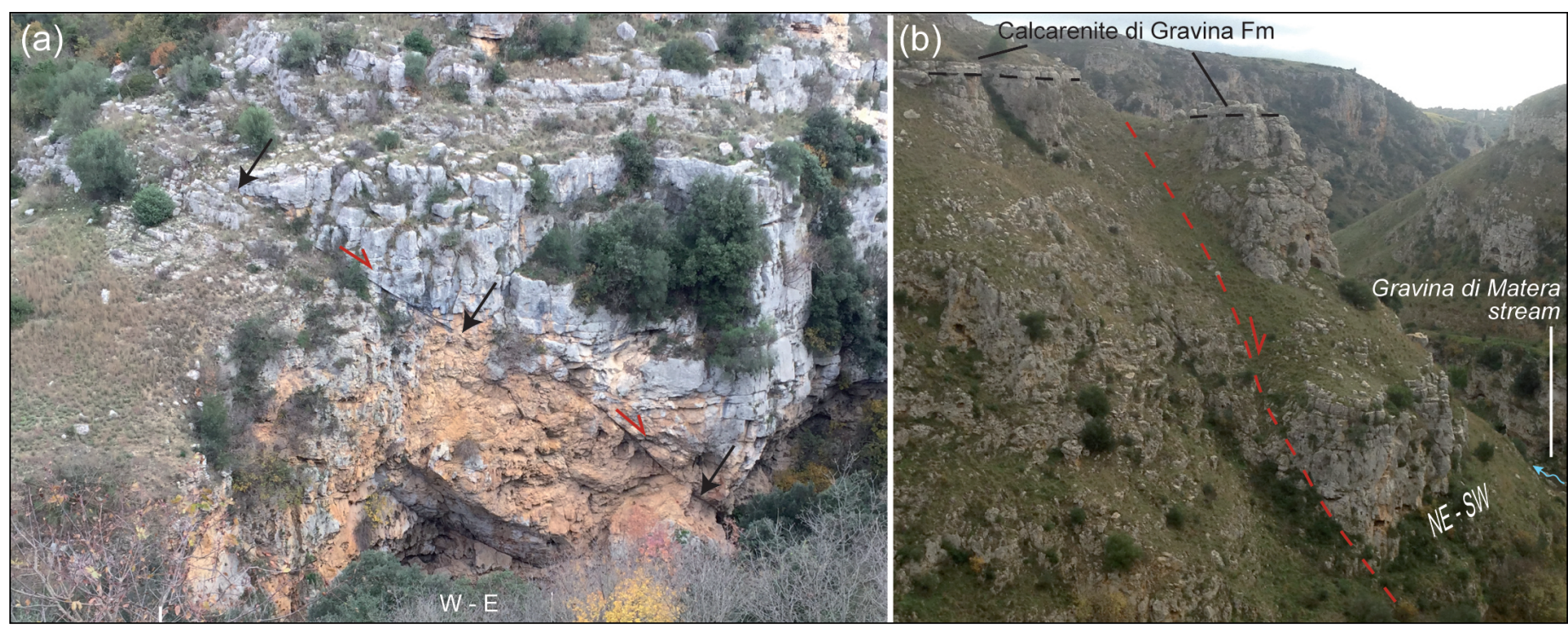

Fig. 10 - (a) Main northeast-dipping normal fault, pointed by the black arrows, on the right slope of the valley eroded by the Jesce stream (i.e., "Torrente Jesce" in the main map; the height of the slope is ca. $15 \mathrm{~m}$ ), near the junction with the "Gravina di Matera" stream (i.e., "Torrente Gravina di Matera" in the main map); an intensely fractured zone, affecting the Cretaceous carbonate rocks, can be appreciated in the footwall of the fault. (b) Main southwest-dipping normal fault (dashed red line) on the left slope of the "Gravina di Matera" canyon (the height of the slope is ca. $80 \mathrm{~m}$ ), displacing of few meters the Calcarenite di Gravina Fm; an intensely fractured zone, affecting the Cretaceous carbonate rocks, can be appreciated in the footwall of the fault. 
50-60 ${ }^{\circ}$ (Fig. 10a). It displaces towards northeast the Cretaceous units, with a throw of ca. $20 \mathrm{~m}$, and it is bordered by an intensely fractured zone and tectonic breccia (Fig. 10a). Its lateral continuation is hidden by the Calcarenite di Gravina Fm, which, however, exhibits a some intensifying of fracturing along the southeastern lateral continuation of the fault.

The main southwest dipping normal fault strikes from the surroundings of San Pietro Caveoso church (to the northwest) to Casalnuovo locality (to the southeast). It plunges ca. $70^{\circ}$, and displaces towards southwest the Cretaceous units, with a throw of ca. $40 \mathrm{~m}$. The fault zone is characterized by intensely fractured limestones and tectonic breccia (Fig. 10b). Along this fault, a small displacement of a few meters affecting also the Calcarenite di Gravina Fm can be appreciated on the left slope of the "Gravina di Matera" canyon (Fig. 10b). In addition, on the right slope of the canyon, an intensifying of fracturing deforming the Calcarenite di Gravina Fm can be locally noticed towards the lateral continuations of the fault.

Other normal faults of minor importance, in terms of throw, dissect, together with their associated synthetic and antithetic faults, the Cretaceous succession. Similarly to the main faults, the mapped minor faults strike ca. northwest-southeast. However, they show higher plunge values of ca. $80^{\circ}$, and throws between $5 \mathrm{~m}$ and $10 \mathrm{~m}$ (e.g. Fig. 3a). Other minor faults are widespread in the Cretaceous succession, however not mapped since their exiguous throw, less than $5 \mathrm{~m}$

\section{DISCUSSION}

\section{ENVIRONMENTAL CONSIDERATIONS}

The lithofacies observations regarding the Cretaceous units were useful not only for proposing stratigraphic subdivision, but also to express some considerations about the development of the Cretaceous succession.

Local features of the unit a resemble those of an internal breccia (sensu FüchtBAuER \& Richter, 1983), that represents the product of an in situ fragmentation of shallow marine deposits induced by flexure-like deformations. At the outcrop scale, flexure and fragmentation can be induced either by large-scale slumps or by small fold propagation faults (WINTERER et alii, 1991). The diffused slump structures in the unit $b$ are the typical sedimentary products of unstable margins, even if slumps may produce in peritidal sediments due to very limited movements along a gentle slope (SPALluto et alii, 2007). Dolostone of the unit c shows a crystalline texture and so it is difficult to identify its original environment, also because dolomite may form in many different diagenetic environments. It is possible to assume that the original sediment developed in a relative deep marine environment since it lies between the unit $b$, that records slump processes typical of slope environments, and the unit d, that contains cherty limestones, typically considered as basinal rocks in the Cretaceous carbonate succession of the Apulia Foreland (MarTINIS \& PAVAN, 1967). Anyway, we underline that, according to PеттілонN (1975), a shallow marine or an hypersaline lacustrine origin can not be excluded for the chert. Unit e is sandwiched between the underlying basinal unit $\mathrm{d}$ and the overlying cahotic breccia characterizing the unit $\mathrm{f}$. Since the latter is a debris deposit that tipically accumulates along and at the base of a steep slope and is produced by repeated collapses of a prograding platform margin (VERWER et alii, 2013), it results that the unit e also deposited in relatively deep environment. Finally, unit g shows in its upper part subtidal and peritidal cycles that are features of sediments developed in a shallow marine carbonate platform, and that can be compared to those features regionally described for the upper Cretaceous succession of the whole Murge area.

\section{Lithostratigraphic Implications: The Matera MEMBER}

One of the main must of the geological cartography is to adopt a stratigraphic subdivision/hierachy that takes into account both previous formal choice of the official cartography and international rules about stratigraphy. On very-large-scale geological-maps, like that one proposed in this work, facies features or other lithostratigraphic attributes are used to identify different informal units within official formations. In a first step of our survey this was the goal of the work. Soon it was clear that most of the Cretaceous facies cropping out in the Matera area show lithological and sedimentological features that strongly differ from those that define in origin the Calcare di Altamura Fm, excluding limestones of the unit $\mathrm{g}$.

The Calcare di Altamura Fm, whose age regionally spans from the late Turonian (dubitative) to the Maastricthian $p . p$., was formally introduced during the 1:100,000 geological survey of the Murge area, where it crops out diffusely (Fig. 1) and reaches $1 \mathrm{~km}$ in thickness (AzzAroli et alii, 1968). Basically it is characterized by shallowing upward cycles with rudists facies and developed in inner carbonate-platform environments (CIARANFI et alii, 1988). Despite this regional description, the Calcare di Altamura Fm in some localities shows facies that differ from inner platform ones, like in the vicinity of Ostuni (east Murge; Fig. 1), where a tectonic retreat of the eastern margin of the platform is recorded by slope to basin deposits developed onto inner platform ones (Borgomano \& PHILIP, 1987; Pieri \& Laviano, 1989; Borgomano, 2000). In this area has been suggested to introduce new formational units (still not adopted) in order to better highlight these lithostratigraphic features and, in particular, the differences with respect to the lithofacies that define and characterize the Calcare di Altamura Fm (Luperto SinNI \& Borgomano, 1989). In other two localities of the Apulia Foreland, away from the Murge area, namely in the vicinity of Apricena (west Gargano; Morsilli et alii, 2002; Fig. 1) and at Porto Selvaggio (west Salento; Mastrogiacomo et alii, 2012; Fig. 1), upper Cretaceous slope to basin facies replace inner platform ones. In the first locality, the new Geological map of Italy at the scale 1:50,000 (Sheet 396 "San Severo"; Servizio Geologico d'Italia, 2011a) ascribed the slope to basin succession to the Calcari di Monte Acuto Fm, lying on the Calcare di Altamura Fm (MoretTI et alii, 2011).

As regards the surveyed area of Matera, facies features described for the units below the unit $\mathrm{g}$ cannot be simply ascribed to the Calcare di Altamura Fm. The whole studied succession starts with facies (unit a) that even if can be ascribed to shallow marine environments, promptly were interested by in situ brecciation, a phenomenon that often is the precursor of deep changes in a carbonate platform. These facies progressively pass upward to slope and basin ones (units b-f), before the restarting of typical facies 
of shallow-marine carbonate platform environments (unit g). To avoid confusion with the official cartography of the area, namely the 1:100,000 Sheet 189 "Altamura" (SERVIzIO Geologico d'Italia, 1968) and Sheet 201 "Matera” (Servizio Geologico d'Italia, 1971), after the subdivision in informal units for so many lithosomes, the adopted solution was to informally define a member, the Matera member, within the Calcare di Altamura Fm. So, the Matera member, that shows a suite of facies belonging to environments referable either to unstable margins or to slopes or to a shallow basin, remains part of the Calcare di Altamura Fm and may have an own cartographic identity. Besides representing the base for the large-scale survey of the present main map, this adopted solution will be useful for small scale maps, when the area will be interested by the new official geological survey. Since ALT is the unequivocal official acronym for the Calcare di Altamura Fm, the acronym ALT has been here adopted for the Matera member, in accordance with the rules enacted by the International Stratigraphic Commission (HEdBerg, 1976). In the study area six lithofacies or lithosomes have been recognized within the Matera member, corresponding to the mapped units from a to $f$. In accordance with the quoted rules, $\mathrm{ALT}_{1 \mathrm{a}}, \mathrm{ALT}_{1 \mathrm{~b}}, \mathrm{ALT}_{1 \mathrm{c}}$, $\mathrm{ALT}_{1 \mathrm{~d}}, \mathrm{ALT}_{1 \mathrm{e}}$, and $\mathrm{ALT}_{1 \mathrm{f}}$ are the adopted acronym for these units. Finally, for all practical purpose, the unit g does not belong to the Matera member but is part of the "classic" Calcare di Altamura Fm (ALT in the main map).

\section{REGIONAL CONSIDERATIONS}

The development of slope to basin facies in the Apulia Platform is recorded in a few localities; it has been hypothesized to being induced by upper Cretaceous tectonics, with the retreat of the eastern platform margin at Ostuni (Pieri \& Laviano, 1989) (Fig. 1), or with the creation of an intraplatform basin at Apricena (Morsilli et alii, 2002) (Fig. 1) and at Porto Selvaggio (Mastrogiacomo et alii, 2012) (Fig. 1). Furthermore, subsurface evidences within the Apulia Platform of upper Cretaceous intraplatform basins (i.e., Rosaria Mare, east of Brindisi, and Casalbordino Corridor, north of Gargano), which formed as a result of extensional tectonics, have been found in the Adriatic offshore thanks to deep wells logs and seismic lines interpretation (NICOLAI \& GAMBINI, 2007; SANTANTONIO et alii, 2013).

In the Murge area, upper Cretaceous extensional tectonics was hypothesized by PIERI (1980) on the basis of regional stratigraphic considerations and, later, constrained by FESTA (2003), on the basis of analyses of tectonic deformations involving inner platform facies. SPALLuto et alii (2007) assumed upper Cretaceous tectonics to play a role for slumps involving peritidal limestones, observed south of Ostuni (Fig. 1). This tectonics may have promoted the development of intraplatform basins, as supported by local stratigraphic evidences. LAVIANO et alii (1998) hypothesized the development of a shallow intraplatform-basin to justify the progradation toward west of clinobedded rudist lithosomes, locally observed just below the Calcare di Altamura Fm, in the late Cenomanian part of the Calcare di Bari Fm (Fig. 1). More recently, and in the same portion of this latter formation, the development of a shallow basin was invoked also by PIERI et alii (2011) for the deposition of marginal shoal, and shallow basin limestones (Sheet 438 "Bari”; Servizio Geologico d’Italia, 2011b).
The geological survey performed along the "Gravina di Matera" canyon indicates the presence of another upper Cretaceous intraplatform-basin located about $100 \mathrm{~km}$ landward with respect to the eastern margin of the Apulia Platform (see RicchetTI, 1980, for the Cretaceous margin position). The moderate thickness of the basin-related succession (i.e. the about $150 \mathrm{~m}$ of the Matera member) suggests that the basin never hosted deep water settings, and, tentatively, the succession could be related to a ramp system developed along a margin of an extensional or cratonic-interior shallow-basin, where, according to BURCHETTE \& WRIGHT (1992), "the identification of truly basinal deposits is a persistent problem".

In Italy, the presence of intraplatform basins has been recognized in the Southern Alps, where extensional/transtentional tectonics affected the Dolomia Principale during the Norian (JAdoul et alii, , 1992; TrombetTA, 1992; BERRA et alii, 2010), in Campania, within the Cretaceous units of the Matese area (CARANNANTE et alii, 2009), and in Sicily, within the upper Jurassic-lower Cretaceous units of the Panormide area (BASILONE et alii, 2016).

In the quoted examples of Southern Alps, marginal faults and/or platform to basin facies transitions both crop out and have been well documented (TROMBETTA \& BotToni, 1993; BERRA \& JAdoul, 1996). Coeval and equivalent intraplatform basin facies were also found in central and southern Apennines, most likely linked to tectonics affecting platforms but without the possibility to demonstrate the presence of marginal faults (CIRILLI, 1993; CLIMACO et alii, 1997).

Unfortunately, also the fault or faults responsible for the formation of the basin cannot be documented in the mapped area and they should be sought elsewhere; nevertheless, upper Cretaceous tectonics is indirectly recorded in the Matera area both by the creation of an isolated and relative deeper setting within a shallow-marine realm and by the instability of basin margins, testified by slumps and debris deposits.

On contrast, the mapped faults mainly record a post-Cretaceous to pre-upper Pliocene activity. However, some more recent activity for these faults is testified, along them, by brittle structures locally involving the Calcarenite di Gravina Fm. Furthermore, the parallelism between the neighboring normal faults dissecting the outer ramp of the foreland basin (Tropeano et alii, 1994; PIERI et alii, 1997; Tropeano et alii, 1997) and the mapped faults does not exclude an extensional upper Pliocene - lower Pleistocene tectonics which affected the Matera area as well.

\section{Matera: a GEOTOURISTIC DESTINATION AND A TRAINING GROUND FOR GEOLOGY}

On 17 October 2014 Matera, a small town in Southern Italy already recognized World Heritage Site by UNESCO since 1993, was voted European Capital of Culture 2019. Therefore Matera, devoted to cultural tourism and possessing this 2019 international appeal, can represent a good opportunity to disseminate geological culture too (SABATO et alii, 2018).

The "Sassi di Matera", originated from a prehistoric troglodyte settlement, is represented by dwellings in part derived from the excavation of caves. The latter are well shaped on the side of the "Gravina di Matera" canyon and partially closed towards the outside by simple coverings 


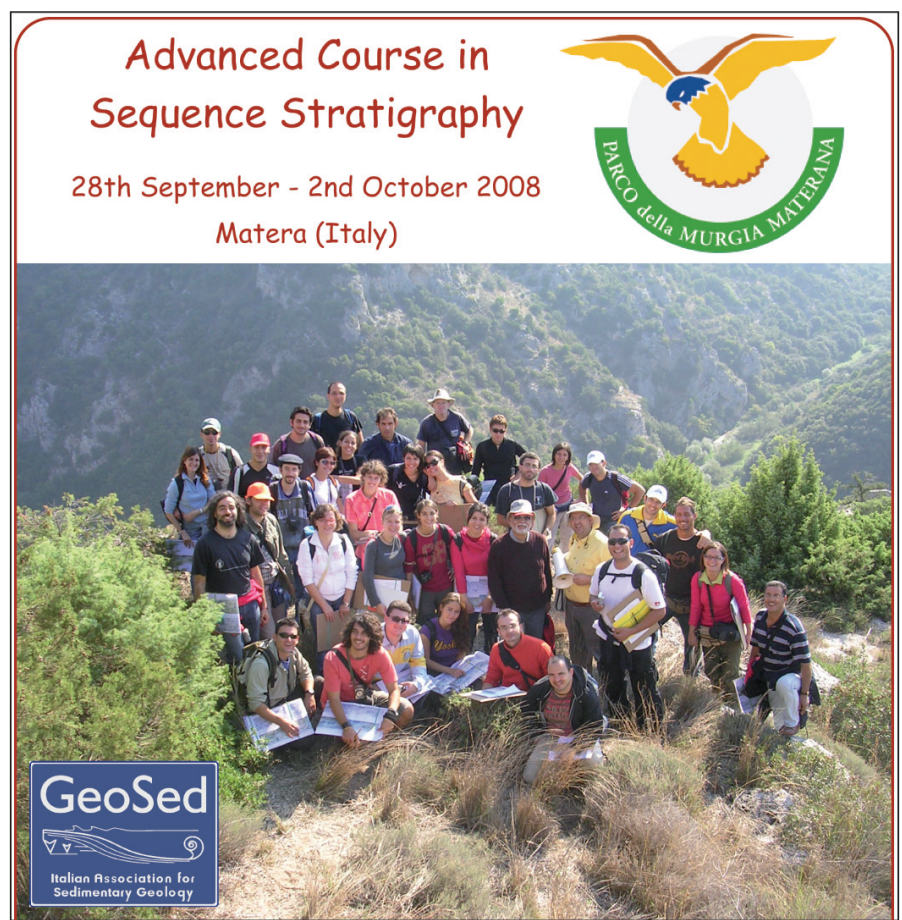

Fig. 11 - Group of undergraduate and Ph.D. students in Geosciences on the brochure of one of the international courses leaded by Bilal $\mathrm{Haq}$ (in the center-right of the group) in the Matera area.

or by more complex building works made up of ashlars derived from rocks of the same type as those excavated. The element of great impact, in addition to the "Sassi di Matera", is really represented by the "Gravina di Matera" canyon, that cut the spur of the Murgia Materana (see the map location in Fig. 2), a Regional Natural Park since the 1990 ("Parco Archeologico Storico Naturale delle Chiese Rupestri del Materano", also known as a "Parco della Murgia Materana" - http://www.parcomurgia.it/).

The "Sassi di Matera" developed inside the Calcarenite di Gravina Fm, and this Quaternary limestones have been and are a training ground for sequence stratigraphy since about 20 years (TROPEANO et alii, 2009). Several field trips and courses performed in the Murgia Materana were dedicated to this topic (Tropeano \& Sabato 2006; Sabato \& TroPEANO, 2008), with a lot of participants coming from all the world that moved along the upper part of the flanks of the "Gravina di Matera" canyon trying to solve field exercises (Fig. 11). Authors of the present paper also accompained on the same sites many groups of schoolchildrens and proposed simplified keys to geological reading the rocks and the landscape (SABATO et alii, 2016; Tropeano et alii, 2016).

Now, with the present study, also the lower part of the canyon and the outcropping Cretaceous succession can represent an useful tool to disseminate the geological knowledge to undergraduate or Ph.D. students in Geosciences, as well as geo-tourists. In fact, the proposed map could be further simplified, realizing an explanatory note for not-geologists. As an instance, the map and all geo-touristic information could be accessible in a dedicated website by a QR (Quick Response) code added on outdoor panel, and used for smartphone or tablet applications.

At the moment, in order to facilitate the use of the main map to do-it-yourself visitors, the most known path- ways starting from the "Sassi di Matera" or from the top of the left side of the "Gravina di Matera" canyon have been traced (see main map).

\section{CONCLUDING REMARKS}

The detailed geological survey of the "Gravina di Matera" canyon along the stretch of "Sassi di Matera", carried out at the scale 1:5,000, allowed us to find an example of upper Cretaceous intraplatform-basin within the wide Apulia Platform. Among other features, slumps, cherty limestones, and a megabreccia horizon are not those ones typical of shallow-marine environments of the interior of a carbonate platform, to which the outcropping succession was previously referred. Since the succession referred to this intraplatform-basin is no more than $150 \mathrm{~m}$ in thickness, reached water depths of the basin were relatively shallow, even if, in absence of other diagnostic criteria, it is difficult to constrain facies to bathymetry.

The presence of a succession with facies referred to relatively deeper environments showing considerable lithological differences from those ones reported in the official geological maps has also implied the necessity to upgrade the formal lithostratigraphic subdivision of the Cretaceous carbonate succession cropping out in the Matera area. The most easy and conservative cartographic solution has been to suggest the institution of a member (the Matera member) within the official formation (the Calcare di Altamura Fm) to which the whole succession belongs.

The new survey and the related map responded to a second, but not secondary, goal. It should be noted that the mapped area: 1) lies in the "Murgia materana", that since the 1990 has been recognized and protected as a regional park for its historical, archeological, and natural features; 2) includes the "Sassi di Matera" districts, that is in the Unesco Word Heritage list since the 1993; 3) may be easily reached by walk from Matera, designated as European Capital of Culture 2019. Therefore, the obtained main map represents not only an essential tool for future studies regarding the evolution of a Cretaceous small basin within the Apulia Platform, but also a guide for those visitors, whose number is exponentially growing, interested to observe the geology exposed along the "Gravina di Matera" canyon. At the moment, in order to facilitate the use of the main map to visitors, the most known pathways starting from the "Sassi di Matera" or from the top of the left side of the canyon have been traced.

\section{ACKNOWLEDGMENTS}

We are grateful to two anonymous reviewers, whose suggestions helped us to improve the manuscript.

We are grateful also to William Cavazza and Fabio Massimo Petti for the editorial management of the manuscript.

We thank Massimo Moretti, Luigi Spalluto, Domenico De Leo and Francesco Quercia for the proficuous discussions in the field.

Dipartimento di Scienze della Terra e Geombientali (Università degli Studi di Bari "Aldo Moro") supported the research with "Futuro in ricercatori” grants.

We thank the Parco Archeologico Storico Naturale delle Chiese Rupestri del Materano, who financed the disclosure and the spread of this research article through both the printing of the offprints and the free download of the .pdf files.

The Municipal Administration of Matera sponsored for free this research paper through the permission to use its institutional logos on the main map. 


\section{REFERENCES}

Abbate E., Bosi C., Castiglioni G.B., Merenda L., Mutti E., Orombelli G., Ortolani F., Parotto M., Pignone R., Polino R., Premoli Silva I. \& SAssi F.P. (1992) - Carta Geologica d'Italia, 1:50.000. Guida al rilevamento. Quaderni Serv. Geol. Naz., serie III, 1, 203 pp.

Azzaroli A., Radina B., Ricchetti G., \& Valduga A. (1968) - Note Illustrative della Carta Geologica d'Italia alla Scala 1:100.000, Foglio 189, Altamura. Serv. Geol. d'It., 21 pp.

Baldassarre G. (1990) - Zonazione geologico-tecnica della Città di Matera. Geol. Appl. e Idrogeol., 25, 181-191.

Basilone L., Sulli A. \& Morticelli M.G. (2016) - Integrating facies and structural analyses with subsidence history in a Jurassic-Cretaceous intraplatform basin: Outcome for paleogeography of the Panormide Southern Tethyan margin (NW Sicily, Italy). Sed. Geol., 339, 258-272.

Battaglini L., Carta R., D’Angelo S., Delogu D., Falcetti S., Pantaloni M., Papasodaro, F. \& TAcchia D. (2009) - Carta Geologica d'Italia, 1:50.000. Progetto CARG: Modifiche ed integrazioni ai Quaderni n. 2/1996 e n. 6/1997. Quaderni Serv. Geol. d'It., serie III, 12 (1), ISPRA - Dipartimento Difesa del Suolo, $166 \mathrm{pp}$.

Beneduce P., Festa V., Francioso R., Schiattarella M., \& Tropeano M. (2004). Conflicting drainage patterns in the Matera Horst area, southern Italy. Physics and Chemistry of the Earth, 29 (10), 717-724.

Berra F. \& Jadoul F. (1996) - Norian Serpulid and Microbial Bioconstructions: Implications for the Platform Evolution in the Lombardy Basin (Southern Alps, Italy). Facies, 35, 143-162.

BerRa F., JADOUL F. \& ANELli A. (2010) - Environmental control on the end of the Dolomia Principale/Hauptdolomit depositional system in the central Alps: Coupling sea-level and climate changes. Paleo. Paleo. Paleo., 290, 138-150.

Boenzi F., Palmentola G., \& Valduga A. (1976) - Caratteri geomorfologici dell'area del Foglio "Matera". Boll. Soc. Geol. It., 95, 527-566.

Boenzi F., Radina B., Ricchetti G., \& Valduga A. (1971) - Note Illustrative della Carta Geologica d'Italia alla Scala 1:100.000, F. 201 Matera. Serv. Geol. d'It., 48 pp.

Borgomano J. (2000) - The Upper Cretaceous carbonates of the Gargano-Murge region, southern Italy: A model to platform-to-basin transition. AAPG Bull., 84 (10), 1561-1588.

Borgomano J. \& Philip J. (1987) - The rudist carbonate build-ups and the gravity carbonates of the Gargano-Apulian margin (southern Italy, Upper Senonian). Mem. Soc. Geol. It., 40, 125-132.

BurchetTE T.P. \& WRIGTH V.P. (1992) - Carbonate ramp depositional systems. Sed. Geol., 79, 3-57.

Carannante G., Pugliese A., Ruberti D., Simone L., Vigliotti M. \& VIgorito M. (2009) - Evoluzione cretacica di un settore della piattaforma apula da dati di sottosuolo e di affioramento (Appennino campano-molisano). Boll. Soc. Geol. It., 128, 3-31.

Ciaranfi N., Maggiore M., Pieri P., Rapisardi L., Ricchetti G. \& Walsh N. (1979) - Considerazioni sulla neotettonica della Fossa Bradanica. Progetto Finalizzato Neotettonica, 251, 73-95.

Ciaranfi N., Pieri P. \& Ricchetti G. (1988) - Note alla Carta Geologica delle Murge e del Salento (Puglia centromeridionale). Mem. Soc. Geol. It., 41, 449-460.

CIrILli S. (1993) - Il Trias di Filettino-Vallepietra (Monti Simbruini, Appennino centrale). Boll. Soc. Geol. It., 112, 371-394.

Climaco A., Boni M., Iannace A. \& Zamparelli V. (1997) - Platform margins, microbial/serpulids bioconstructions and slope-to-basin sediments in the Upper Triassic of the "Verbicaro Unit" (Lucania and Calabria, Southern Italy). Facies, 36, 37-56.

Cosci M., Falcetti S. \& Tacchia D. (1996) - Carta Geologica d'Italia, 1:50.000. Guida alla rappresentazione cartografica. Quaderni Serv. Geol. Naz., serie III, 2, 97 pp.

Cotecchia V. \& Grassi D. (1975) - Stato di conservazione dei "Sassi" di Matera (Basilicata) in rapporto alle condizioni geomorfologiche del territorio e alle condizioni antropiche. Geol. Appl. e Idrogeol., 10 (1), 55-105.

Doglioni C., Mongelli,F., \& Pieri P. (1994) - The Puglia uplift (SE-Italy): an anomaly in the foreland of the Apenninic subduction due to buckling of a thick continental lithosphere. Tectonics, 13, 13091321.

Festa V. (2003) - Cretaceous structural features of the Murge area (Apulian Foreland, Southern Italy). Eclogae Geologica Helvetiae, 96, 11-22.
Fǘhtbauer H. \& RichteR D.K. (1983) - Relations between submarine fissures, internal breccias and mass flows during Triassic and earlier rifting periods. Geologische Rundschau, 72(1), 53-66.

Hedberg H.D. (ed) (1976) - International Stratigraphic Guide - A guide to stratigraphic classification, terminology and procedure. Wiley \& Sons, $200 \mathrm{pp}$.

Jadoul F., BerRa F. \& FrISIA S. (1992) - Stratigraphic and paleogeographic evolution of a carbonate platform in an extensional tectonic regime: the example of the Dolomia Principale in Lombardy. Riv. It. Paleont. Strat., 98(1), 29-44.

Laviano A., Gallo-Maresca M. \& Tropeano M. (1998) - Stratigraphic organization of rudist biogenic beds in the Upper Cenomanian successions of the Western Murge (Apulia, Southern Italy). Geobios, 31 (Suppl.1), 159-168.

Luperto Sinni E. \& Borgomano J. (1989) - Le Crétacé supérieur des Murges sud-orientales (Italie mèridionale): stratigraphie et évolution des paléoenvironnements. Riv. It. Paleontol. Stratigr., 95 (2), 95-136.

Maggiore M., Radina B. \& Walsh N. (1975) - Dissesti e zonizzazione di un'area campione al margine orientale della Fossa Bradanica (dintorni di Matera). Mem. Soc. Geol. It., 14, 283-304.

Martinis B. \& Pavan G. (1967) - Note Illustrative della Carta Geologica d'Italia alla Scala 1:100.000, F. 157, Monte S. Angelo. Serv. Geol. d'It., $56 \mathrm{pp}$.

Mastrogiacomo G., Moretti M., Owen G., \& Spalluto L. (2012) - Tectonic triggering of slump sheets in the Upper Cretaceous carbonate succession of the Porto Selvaggio area (Salento peninsula, southern Italy): Synsedimentary tectonics in the Apulian Carbonate Platform. Sed. Geol., 269-270, 15-27.

Mateu-Vicens G., Pomar L. \& Tropeano M. (2008) - Architectural complexity of a carbonate transgressive systems tract induced by basement physiography. Sedimentology, 55(6), 1815-1848.

Moretti M., Pieri P, Ricchetti G, Spalluto L., con il contributo di Festa V., Maggiore M., Piccarreta G., Ronchitelli A. \& Walsh N. (2011) - Note Illustrative della Carta Geologica d'Italia alla scala 1:50.000, Foglio 396, San Severo. ISPRA, Serv. Geol. d'It., 145 pp.

Morsilli M., De Cosmo P.D., Bosellini A. \& Luciani V. (2002) - L'anneg amento santoniano della Piattaforma Apula nell'area di Apricena (Gargano, Puglia): nuovi dati per la paleogeografia del Cretaceo superiore. Raccolta Riassunti GIS 2002, Pescara, IX Riunione Annuale Gruppo Informale di Sedimentologia, 63-64.

Mucciarelli M., Camassi R., Cristallo F., Francioso R., Gallipoli M.R. Piscitelli S., Rizzo E., Schiattarella M., Sdao F. \& Tropeano M. (2002) - Studi preliminari per una mappatura dei rischi naturali nei Sassi di Matera. Comune di Matera, $90 \mathrm{pp}$.

Nicolai C. \& Gambini R. (2007) - Structural architecture of the Adria platform-and-basin systems. Boll. Soc. Geol. It., Spec. Vol. 7, 21-37.

Petтijohn F. J. (1975) - Sedimentary rocks. 3rd ed. Harper \& Row, 628 pp.

PIERI P. (1980) - Principali caratteri geologici e morfologici delle Murge. Murgia sotterranea, Boll. Gruppo Speleol. Martinense, 2, 13-19.

Pieri P. \& LaVIano A. (1989) - Tettonica e sedimentazione nei depositi Senoniani delle Murge sud-orientali (Ostuni). Boll. Soc. Geol. It., 108, 351-356.

Pieri P., Sabato L. \& Tropeano M. (1996) - Significato geodinamico dei caratteri deposizionali e strutturali della Fossa Bradanica nel Pleistocene. Mem. Soc. Geol. It., 51(1), 501-515.

Pieri P., Festa V., Moretti M. \& Tropeano M. (1997) - Quaternary tectonic activity of the Murge area. (Apulian foreland - Socuthern Italy). Ann. Geofis., 40(5), 1395-1404.

Pieri P., Spalluto L., Sabato L., Tropeano M., con il contributo di andriani G.F., Caffau M., Labriola M., Maggiore M., Marino M. \& Walsh N. (2011) - Note Illustrative della Carta Geologica d'Italia alla scala 1:50.000, Foglio 438, Bari. ISPRA, Serv. Geol. d'It., $105 \mathrm{pp}$.

Pomar L. \& Tropeano M. (2001) - The Calcarenite di Gravina formation in Matera (Southern Italy): New insights for coarse-grained, largescale, cross-bebbed bodies encased in offshore deposits. AAPG Bull., 85(4), 661-689.

RAdina B. (1973) - Saggio e note illustrative di una carta geologico-tecnica: (Tav. 189 III SE “Matera Nord"). Geol. Appl. e Idrogeol., 8(2), 89-105.

Riccheтti G. (1980) - Contributo alla conoscenza strutturale della Fossa bradanica e delle Murge. Boll. Soc. Geol. It., 99, 421-430. 
Ricchetti G., Ciaranfi N., Luperto Sinni E., Mongelli F. \& Pieri P. (1988) Geodinamica ed evoluzione sedimentaria e tettonica dell'Avampaese Apulo. Mem. Soc. Geol. It., 41, 57-82.

Sabato L. \& Tropeano M. (Eds) (2008) - Plio-Pleistocene stratigraphic and tectonic evolution of the Southern Italy foredeep: key examples from South Apennines front and Bradanic Trough (Basilicata Region) Field Guide. GeoSed 2008, Pre-Congress Field Trip, 124pp.

Sabato L., Tropeano M., dell'Olio M. \& Longhitano S.G. (2016) Matera-Grassano-Aliano: la geologia seguendo le orme di Carlo Levi. GTA Geologia Territorio Ambiente, Rivista dell'Ordine dei Geologi di Basilicata, 25, 54-67.

Sabato L., Tropeano M., Festa V., dell'Olio M. \& Longhitano S.G. (2018) - Following Writings and Paintings by Carlo Levi to Promote Geology within the "Matera-Basilicata 2019, European Capital of Culture” Events (Matera, Grassano, Aliano - Southern Italy). Geoheritage, doi: 10.177/s12371-018-0281-4.

Salvador A. (ed.) (1994) - International Stratigraphic Guide - A guide to stratigraphic classification, terminology and procedure. Int. Un. of Geol. Sc. and Geol. Soc. of America, 214 pp.

Santantonio M., Scrocca D. \& Lipparini L. (2013) - The Ombrina-Rospo Plateau (Apulian Platform): Evolution of a Carbonate Platform and its Margins during the Jurassic and Cretaceous. Mar. Petrol. Geol., 42, 4-29.

Sella M., Turci C, \& Riva A. (1988) - Sintesi geopetrolifera della Fossa Bradanica (avanfossa della catena appenninica meridionale). Mem. Soc. Geol. It., 41, 87-107.

Servizio Geologico d’Italia (1968) - Carta Geologica d'Italia alla Scala $1: 100.000$, F. 189 , Altamura.

Servizio Geologico d'Italia (1971) - Carta Geologica d'Italia alla Scala $1: 100.000$, F. 201, Matera.

Servizio Geologico d'Italia (2011a) - Carta Geologica d'Italia alla scala 1:50.000, Foglio 396, San Severo.

Servizio Geologico d'Italia (2011b) - Carta Geologica d'Italia alla scala 1:50.000, Foglio 438, Bari.

Spalluto L., Moretti M., Festa V. \& Tropeano M. (2007) - Seismically-induced slumps in Lower-Maastrichtian peritidal carbonates of the Apulian Platform (southern Italy). Sedim. Geol., 196, 81-98.

Spalluto L., Pieri P. \& Ricchetti G. (2005) - Le facies carbonatiche di piattaforma interna del Promontorio del Gargano: implicazioni paleoambientali e correlazioni con la coeva successione delle Murge. Boll. Soc. Geol. It., 124, 675-690.

Tacchia D. (2007) - Carta Geologica d'Italia, 1:50.000. Guida all'uso del manuale cromatico di riferimento per la stampa delle carte geologiche. Quaderni Serv. Geol. d’It, serie III, 11, APAT - Dipartimento Difesa del Suolo, 84 pp.
Trombetta L.G. (1992) - Tettonica transtensiva, bacini di pull-apart e sedimentazione nel Norico delle Prealpi Bresciane. Atti Tic. Sc. Terra, 35, 127-138.

Trombetta L.G. \& Bottoni D. (1993) - Analisi di facies ed evoluzione in $3 D$ in un bacino intra-piattaforma del Norico della Lombardia (Valvestino, Prealpi Bresciane). Mem. Sci. Geol., 45, 149-164.

Tropeano M. (1994) - Caratteri deposizionali della Calcarenite di Gravina (Pliocene superiore-Pleistocene inferiore) sul bordo orientale del la Fossa bradanica nell'area di Matera. Quaderni Bibl. Prov. Matera, 15, 67-86. Edizioni Osanna, Venosa (PZ).

Tropeano M., Boenzi F., Capolongo D., Festa V., Pieri P., Sabato L. \& Schiuma G. (2016) - Ultime notizie da Matera: Tempa Rossa non è un vulcano! GTA Geologia Territorio Ambiente, Rivista dell'Ordine dei Geologi di Basilicata, 25, 45-53.

Tropeano M., Hao B., Longhitano S.G. \& Sabato L. (2009) - Looking for a good training ground for sequence stratigraphy? The Calcarenite di Gravina Formation in Matera (Southern Italy). In: PAscuccI V. \& ANDREucci S. (Eds) Book of Abstracts of the 27th IAS Meeting, 704.

Tropeano M., Marino M. \& Pieri P. (1994) - Evidenze di tettonica disten siva Plio-Pleistocenica al margine orientale della Fossa bradanica: l'Horst di Zagarella. Il Quaternario, 7(2), 597-606.

Tropeano M., Pieri P., Moretti M., Festa V., Calcagnile G., Del Gaudio V. \& PIERRI P. (1997) - Quaternary tectonics and seismotectonic features of the Murge area (Apulian foreland, SE Italy). Il Quaternario, 10(2), 543-548.

Tropeano M. \& Sabato L. (2000) - Response of Plio-Pleistocene mixed bioclastic-lithoclastic temperate-water carbonate systems to forced regressions: the Calcarenite di Gravina Formation, Puglia, SE Italy. In: Hunt D. \& Gawthorpe R.L. (Eds) Sedimentary Responses to Forced Regressions, Geological Society of London, Sp. Publ. 172, 217-243.

Tropeano M. \& SABATo L. (2006). Advanced course in sequence stratigraphy - field guide. pp. 47. BARI: GeoSed (ITALY). 47 pp.

Tropeano M., Sabato L. \& Pieri P. (2002) - Filling and cannibalization of a foredeep: The Bradanic Trough, southern Italy. In: Jones S.J. \& Frostick L.E. (Eds) Sediment Flux to Basins: Causes, Controls and Consequences. Geological Society of London, Sp. Publ., 191, 55-79.

Verwer K., Playton T.E. \& Harris P.M. (2013) - Deposits, architecture, and controls of carbonate margin, slope, and basinal settings-introduction. In: Verwer K., Playton T.E. \& Harris P.M. (Eds) Deposits, architecture, and controls of carbonate margin, slope, and basinal settings. SEPM Sp. Publ, 105, 1-13.

Winterer E.L., Metzel C.V. \& SArti M. (1991) - Neptunian dykes and associated breccias (Southern Alps, Italy and Switzerland): role of gravity sliding in open and closed systems. Sedimentology, 38, 381-404. 